\title{
Comparison between plasma neopterin and the urine neopterin:creatinine ratio as inflammatory biomarkers
}

\author{
Bianca Thomas ${ }^{1}$, Priyesh Bipath ${ }^{2}$, Margaretha Viljoen ${ }^{3}$
}

1. Department of Human Anatomy and Physiology, Faculty of Health Sciences, University of Johannesburg, South Africa.

2. Department of Physiology, School of Medicine, Faculty of Health Sciences, University of Pretoria, South Africa.

3. Department of Psychiatry, School of Medicine, Faculty of Health Sciences, University of Pretoria, South Africa.

\section{Authors' details:}

Priyesh Bipath, Tel: +27 12 3192424, Email: priyesh.bipath@up.ac.za; Margaretha Viljoen, Tel: +27 123293090, Email: mviljoen@webafrica.org.za

\begin{abstract}
Background: Neopterin, a product of cell-mediated immunity, is a non-specific biomarker of inflammation. Plasma/serum is generally the body fluid of choice for neopterin assessment, but urine is often used as it does away with venepuncture. Analysis of urine neopterin is based on collection of a single urine sample and expressed as $\mu \mathrm{mol}$ neopterin $/ \mathrm{mol}$ creatinine.

Objectives: To examine published correlations between plasma neopterin levels and urine neopterin:creatinine ratios and to determine whether they are in diagnostic agreement.

Methods: Literature search was performed by databases and by hand. Databases included Academic Search Complete; Africa-Wide Information; AHFS Consumer Medication Information; eBook Collection (EBSCOhost); Family \& Society Studies Worldwide; MasterFILE Premier; MEDLINE; TOC Premier.

Results: Positive correlations of varying statistical significance generally exist between plasma neopterin and urine neopterin:creatinine ratios. With a decline in renal clearance, plasma neopterin over-estimates inflammatory activity. With immune-complex renal disease, urine neopterin:creatinine ratios over-estimate systemic inflammation. The two biomarkers can differ in diagnostic validity.

Conclusion: Correlations between plasma neopterin and urine neopterin:creatinine ratios suggest both as suitable biomarkers. However, since correlations reflect equality of means and not individual values, significant correlations, do not necessarily imply diagnostic agreement. Therefore, plasma and urine cannot summarily be assumed interchangeable for diagnostic/prognostic purposes.
\end{abstract}

Keywords: Neopterin, inflammation, biomarkers, renal, creatinine.

DOI: https://dx.doi.org/10.4314/ahs.v19i3.14

Cite as: Thomas B, Bipath P, Viljoen M. Comparison between plasma neopterin and the urine neopterin:creatinine ratio as inflammatory biomarkers. Afri Health Sci. 2019;19(3): 2407-2413. bttps:/ / dx.doi.org/10.4314/abs.v19i3.14

\section{Corresponding author:}

Bianca Thomas,

Department of Human Anatomy and Physiology,

Faculty of Health Sciences, University of

Johannesburg,

P. O. Box 524, Auckland Park,

2006, South Africa

Tel: +27115596250

Email: bthomas@uj.ac.za

\section{Introduction}

Inflammatory mediators are involved in virtually all normal physiological and psychological/mental processes in the body ${ }^{1}$. In addition to their role in the regulation of peripheral immune, cardiovascular, metabolic and other activities, they are essential for normal central nervous system processes such as synaptic plasticity, neurogenesis and neuromodulation ${ }^{2}$. On the downside, excessive inflammatory activity has been reported in association with a host of physical disorders, not only infectious and

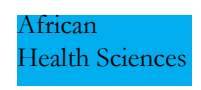

(C) 2019 Thomas et al. Licensee African Health Sciences. This is an Open Access article distributed under the terms of the Creative commons Attribution License (https://creativecommons.org/licenses/BY/4.0), which permits unrestricted use, distribution, and reproduction in any medium, provided the original work is properly cited. 
inflammatory conditions, but also metabolic-, cardiovascular-, skeletal- and nutrition-related disturbances not primarily associated with inflammatory processes ${ }^{3,4}$. Likewise for psychiatric and cognitive disorders, where abnormal inflammatory status is known to occur in a wide variety of psychiatric syndromes ${ }^{3,5}$ and to have detrimental effects on memory, neural plasticity and neurogenesis ${ }^{2,6}$. In fact, inflammation has been shown to be a common denominator in more physical and neuropsychiatric disorders than ever before anticipated ${ }^{3,5,7}$.

In view of the central role of inflammatory processes in health and disease, a variety of specific, as well as non-specific, inflammatory biomarkers are measured in research and in clinical medicine, in an attempt to estimate a patient's inflammatory status, as well as to monitor disease progression or the effects of therapeutic interventions. Neopterin, a product of cell-mediated immunity, is probably, among the non-specific biomarkers most often employed as an inflammatory biomarker ${ }^{8}$.

Neopterin has been shown, both in our laboratory and in that of others, ${ }^{8}$ to be a good non-specific indicator of pro-inflammatory activity and a useful biomarker in numerous infectious and non-infectious disorders, including many not previously associated with cellular immune activity. As such it is commonly used to estimate inflammatory status and prognosis, as well as to monitor the progression of disease, the effects of therapeutic interventions, and to estimate exposure to toxic industrial substances $^{8-13}$.

Plasma or serum is generally the body fluid of choice for the assessment of neopterin levels ${ }^{10,11}$. However, a multitude of studies exist where urine neopterin levels, rather than plasma levels, have been determined as biomarkers ${ }^{10}$. Analysis of urine neopterin is, in the majority of cases, based on the collection of a single urine sample and expressed as $\mu \mathrm{mol}$ neopterin/mol creatinine. Although the handling of urine from infectious patients may carry a smaller risk than plasma ${ }^{11}$, the reason, in the majority of studies, for using urine rather than plasma is that it does away with the need for venepuncture.

Both plasma and urine neopterin increase with increases in cell-mediated immunity. Authorities in the field, as early as 1992, already claimed that neopterin concentrations in serum and in urine increase in parallel to the clinical course of infections and are significant predictors of disease progression ${ }^{11}$. Whether such a linear relationship between plasma neopterin levels and the urine neopterin:creatinine ratio does indeed invariable exist and, perhaps more importantly, whether these two markers exhibit diagnostic agreement, is of practical interest. This paper examines published correlations between plasma neopterin levels and the urine neopterin:creatinine ratio and addresses the question of whether diagnostic agreement exists between the two, i.e., whether they can be considered interchangeable for diagnostic or prognostic purposes.

\section{Methods}

Literature searches were performed by databases and by hand. Databases used included Academic Search Complete; Africa-Wide Information; AHFS Consumer Medication Information; eBook Collection (EBSCOhost); E-Journals; Family \& Society Studies Worldwide; Health Source: Consumer Edition; Health Source: Nursing/Academic Edition; MasterFILE Premier; MEDLINE; TOC Premier.

\section{Results}

Most studies assessed neopterin in either plasma/serum or in urine. Nevertheless, a fair number of studies could be found where neopterin was measured in plasma or serum, as well as in urine. Unfortunately, about two thirds of them did not report correlations. Studies that did report on the correlations between serum/plasma levels and the urine neopterin:creatinine ratio are summarized in Table 1. Correlations varied from non-significant to highly significant, with the majority showing some sort of statistically significant correlation between the two. The diagnostic agreement/non-agreement between the results of each study is given in the fifth column of Table 1. 
Table 1: Correlations and diagnostic agreement between plasma neopterin levels and

the urine neopterin: creatinine ratio

\begin{tabular}{|c|c|c|c|c|c|}
\hline Patients & $\begin{array}{l}\text { Plasma/serum neopterin } \\
(\mathrm{nmo/L})\end{array}$ & $\begin{array}{l}\text { Urine neopterin } \\
(\mu m o l / m o l \text { creatinine })\end{array}$ & $\begin{array}{l}\text { Correlation co-efficient; } \\
\text { (p-value) }\end{array}$ & $\begin{array}{l}\text { Diagnostic } \\
\text { agreement/non- } \\
\text { agreement }\end{array}$ & Reference \\
\hline $\begin{array}{l}\text { Patients with rectal } \\
\text { carcinoma undergoing } \\
\text { chemorad iation }(n=49) \\
\text { Week } 1(n=49) \\
\text { Week } 2(n=46) \\
\text { Week } 3(n=44) \\
\text { Week } 4(n=44) \\
\text { Week } 5(n=43) \\
\text { Week } 6(n=42) \\
\text { Week } 7(n=36) \\
\text { No controls }\end{array}$ & $\begin{array}{l}11.1 \pm 13.0 \\
13.3 \pm 17.2 \\
9.7 \pm 5.6 \\
9.5 \pm 4.7 \\
11.2 \pm 6.5 \\
10.7 \pm 5.4 \\
12.3 \pm 9.5 \\
\text { measured by } \\
\text { radioimmunoassay (RIA) }\end{array}$ & $\begin{array}{l}197 \pm 102 \\
254 \pm 201 \\
243 \pm 188 \\
213 \pm 106 \\
248 \pm 148 \\
251 \pm 144 \\
313 \pm 281 \\
\text { measured by high } \\
\text { performance liquid } \\
\text { chromatography (HPLC) }\end{array}$ & $\begin{array}{l}r_{\mathrm{s}}=0.707 ;(<0.000001) \\
\mathrm{r}_{\mathrm{s}}=0.557 ;(0.0001) \\
\mathrm{r}_{\mathrm{s}}=0.552 ;(0.0001) \\
\mathrm{r}_{\mathrm{s}}=0.770 ;(<0.000001) \\
\mathrm{r}_{\mathrm{s}}=0.439 ;(0.003) \\
\mathrm{r}_{\mathrm{s}}=0.466 ;(0.002) \\
\mathrm{r}_{\mathrm{s}}=0.589 ;(0.0002)\end{array}$ & $\begin{array}{l}\text { Only the urine } \\
\text { neopterin:creatinine ratios } \\
\text { were associated with the } \\
\text { irradiated gut volume. } \\
\text { Serum } \\
\text { neopterin:creatinine ratio } \\
\text { correlated with the } \\
\text { toxicity of the therapy } \\
\text { more closely than the } \\
\text { absolute serum neopterin } \\
\text { concentrations. }\end{array}$ & [24] \\
\hline $\begin{array}{l}\text { Zinc-exposed } \\
\text { galvanization workers } \\
(\mathrm{n}=63) \\
\text { Controls }(\mathrm{n}=23)\end{array}$ & $\begin{array}{l}9.55 \pm 0.49 \\
\\
5.55 \pm 0.54 \\
\text { measured by enzyme- } \\
\text { linked } \\
\text { immunosorbent assay } \\
\text { (ELISA) }\end{array}$ & $\begin{array}{l}141 \pm 5.95 \\
\text { measured by HPLC }\end{array}$ & $\begin{array}{l}r_{s}=0.265 ;(0.037) \text { for } \\
\text { entire group }\end{array}$ & $\begin{array}{l}\text { Urine neopterin:creatinine } \\
\text { ratios and not plasma } \\
\text { neopterin correlated with } \\
\text { serum zinc levels. }\end{array}$ & [25] \\
\hline 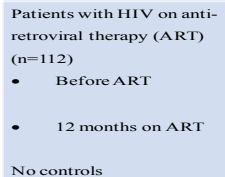 & $\begin{array}{l}19.6(12.1-30.0) \\
7.3(4.7-10.6) \\
\text { measured by ELISA }\end{array}$ & $\begin{array}{l}554(414-859) \\
231(157-309) \\
\text { measured by HPLC }\end{array}$ & $\begin{array}{l}r_{s} \text { only given for changes } \\
(\Delta) \text {. }\end{array}$ & $\begin{array}{l}\text { Both plasma and urine } \\
\text { neopterin were } \\
\text { significantly raised before } \\
\text { ART. Following ART } \Delta \\
\text { urine neopterin:creatinine } \\
\text { correlated with } \triangle \text { plasma } \\
\text { neopterin } \\
r_{\mathrm{s}}=0.758 ;(<0.001)\end{array}$ & [26] \\
\hline $\begin{array}{l}\text { Patients on haemodialysis } \\
\text { Controls }\end{array}$ & $\begin{array}{l}38 \pm 0.5(n=71) \\
11 \pm 1(n=21) \\
\text { measured by ELISA }\end{array}$ & $\begin{array}{l}381 \pm 29(n=37) \\
122 \pm 16(n=20) \\
\text { measured by HPLC }\end{array}$ & $\begin{array}{l}r=0.286(0.148) \\
r_{s}=0.784 ;(<0.001)\end{array}$ & $\begin{array}{l}\text { Duration (yrs) on } \\
\text { haemodialysis } \\
\text { significantly influenced } \\
\text { urinary } \\
\text { neopterin:creatinine ratio, } \\
\text { but not plasma neopterin } \\
\text { levels }\end{array}$ & [27] \\
\hline $\begin{array}{l}\text { Patients with Behcet's } \\
\text { disease }(n=45) \\
\text { Controls }(n=45)\end{array}$ & $\begin{array}{l}12.68 \pm 4.87 \\
6.03 \pm 3.46 \\
\text { measured by ELISA }\end{array}$ & $\begin{array}{l}167.53 \pm 148.73 \\
104.15 \pm 47.74 \\
\text { measured by ELISA }\end{array}$ & $r=0.38 ;(0.008)$ & $\begin{array}{l}\text { Moderate negative } \\
\text { correlation between } \\
\text { serum neopterin and IFN- } \\
\gamma \text { levels, however no } \\
\text { correlation between urine } \\
\text { neopterin:creatinine ratio } \\
\text { and serum IFN- } \gamma \text { levels. }\end{array}$ & [28] \\
\hline 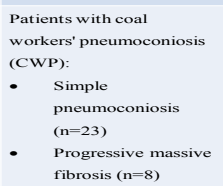 & $\begin{array}{l}10.72 \pm 0.98 \\
14.08 \pm 3.86\end{array}$ & $\begin{array}{l}235.17 \pm 7.40 \\
256.05 \pm 9.43\end{array}$ & $\begin{array}{l}\text { For all participants: } \\
r=0.525,(<0.01)\end{array}$ & $\begin{array}{l}\text { Patient serum neopterin } \\
\text { levels in CWP were } \\
\text { higher than controls, } \\
\text { while urine } \\
\text { neopterin:creatinine } \\
\text { levels were within the } \\
\text { normal range. }\end{array}$ & [17] \\
\hline Controls $(n=26)$ & $\begin{array}{l}5.30 \pm 0.47 \\
\text { measured by ELISA }\end{array}$ & $\begin{array}{l}140.00 \pm 5.43 \\
\text { measured by ELISA }\end{array}$ & & & \\
\hline $\begin{array}{l}\text { Patients with tuberculous } \\
\text { pleurisy }(n=34) \\
\text { Patients with non- } \\
\text { tuberculous pleural } \\
\text { effusion }(n=29)\end{array}$ & $\begin{array}{l}38.28 \pm 14.18 \\
22.57 \pm 6.02 \\
\text { measured by HPLC }\end{array}$ & $\begin{array}{l}759.15 \pm 622.74 \\
\begin{array}{l}343.10 \pm 233.65 \\
\text { measured by HPLC }\end{array}\end{array}$ & $\begin{array}{l}\mathrm{r}=0.73 ;(<0.001) \\
\text { Not reported }\end{array}$ & $\begin{array}{l}\text { Serum neopterin showed } \\
\text { a diagnostic sensitivity of } \\
56 \% \text {, while the diagnostic } \\
\text { sensitivity of the urine } \\
\text { neopterin:creatinine ratio } \\
\text { was only } 26 \% \text {. }\end{array}$ & [29] \\
\hline No controls & & & & & \\
\hline $\begin{array}{l}\begin{array}{l}\text { Patients with pulmonary } \\
\text { tuberculosis }(\mathrm{n}=38)\end{array} \\
\begin{array}{l}\text { Patients with bronchial } \\
\text { carcinoma ( } \mathrm{n}=13)\end{array} \\
\begin{array}{l}\text { Patients with pneumonia } \\
(\mathrm{n}=20)\end{array} \\
\text { Healthy volunteers ( } \mathrm{n}=24)\end{array}$ & $\begin{array}{l}6.2 \pm 1.7 \\
\text { measured by RIA }\end{array}$ & $\begin{array}{l}225.6 \pm 69.6 \\
141.8 \pm 36.9 \\
\text { measured by HPLC }\end{array}$ & $\begin{array}{l}\mathrm{r}=0.70 ;(<0.011) \\
\mathrm{r}=0.72 ;(0.001) \\
\mathrm{r}=0.90 ;(<0.001)\end{array}$ & $\begin{array}{l}\text { The increase of neopterin } \\
\text { above normal was } \\
\text { markedly higher for urine } \\
\text { than for serum. A } \\
\text { positive correlation was } \\
\text { found between the } \\
\text { radiological extent of the } \\
\text { disease and the urine } \\
\text { neopterin:creatinine ratio, } \\
\text { but not between the } \\
\text { radiological extent of the } \\
\text { disease and serum } \\
\text { neopterin values. }\end{array}$ & [30] \\
\hline $\begin{array}{l}\text { Patients with juvenile } \\
\text { idiopathic inflammatory } \\
\text { myopathies } \\
\text { Controls }\end{array}$ & $\begin{array}{l}1.5(\mathrm{n}=35) \\
\text { measured by ELISA }\end{array}$ & $\begin{array}{l}1.7 \mu \mathrm{mol} / \mathrm{L}(\mathrm{n}=79) \\
\text { measured by HPLC }\end{array}$ & $\begin{array}{l}\text { No significant } \\
\text { correlations }\end{array}$ & $\begin{array}{l}\text { Urine neopterin correlated } \\
\text { significantly with various } \\
\text { clinical measures of } \\
\text { myositis disease activity, } \\
\text { while plasma neopterin } \\
\text { did not correlate with } \\
\text { these same myositis } \\
\text { disease activity measures. }\end{array}$ & [18] \\
\hline $\begin{array}{l}\begin{array}{l}\text { Renal allograft recipients } \\
(\mathrm{n}=30)\end{array} \\
\text { No controls }\end{array}$ & $\begin{array}{l}\text { Not reported } \\
\text { measured by RIA }\end{array}$ & $\begin{array}{l}\text { Not reported } \\
\text { measured by HPLC }\end{array}$ & $\begin{array}{l}\mathrm{r}=0.269(0.190 \text { to } 0.345) ; \\
\mathrm{p} \text {-value not reported } \\
\text { Relating serum neopterin } \\
\text { to serum creatinine } \\
\text { improved correlation to } \\
\mathrm{r}=0.779(0.750-0.805)\end{array}$ & $\begin{array}{l}\text { Serum neopterin is not an } \\
\text { adequate biomarker in } \\
\text { renal disease, and should } \\
\text { be expressed relative to } \\
\text { serum creatinine (as for } \\
\text { urine). }\end{array}$ & [15] \\
\hline 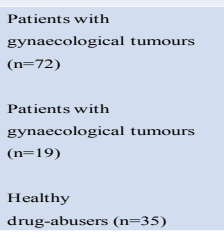 & $\begin{array}{l}\text { Patient values presented } \\
\text { only as scatter plots } \\
\text { measured by RIA }\end{array}$ & $\begin{array}{l}\text { Patient values presented } \\
\text { only as scatter plots } \\
\text { measured by HPLC }\end{array}$ & $\begin{array}{l}r_{s}=0.60(<0.001) \\
r_{s}=0.40 \\
r_{s}=0.72\end{array}$ & $\begin{array}{l}\text { The discriminatory power } \\
\text { of the urine } \\
\text { neopterin:creatinine ratio } \\
\text { was superior to that of } \\
\text { serum neopterin (chi } \\
\text { square: } 28.87 \mathrm{vs} 17.38 \text { ). }\end{array}$ & [16] \\
\hline
\end{tabular}




\section{Discussion}

As seen in Table 1, correlations between serum/plasma levels and the urine neopterin:creatinine ratio varied from non-significant to highly significant, with the majority showing a statistically significant correlation. As correlation coefficients indicate a linear relationship between two numerical measurements, it would suggest both plasma neopterin and the neopterin:creatinine ratio in urine to be markers of pro-inflammatory status, and suitable for the serial monitoring of disease progression or the effect of therapeutic interventions. This has been suggested by a number of studies and would, in general, be applicable. Some of the correlations were, however, only weakly significant and in a small number of studies not statistically significant at all.

\section{Possible explanations for variations in the linear re- lationship between plasma neopterin and the urine neopterin:creatinine ratio}

In order to better understand the relationship between plasma neopterin and the urine neopterin:creatinine ratio, and thus the potential for variation in their correlation, it is necessary to examine the balance between neopterin input to, and removal from the circulation.

Neopterin is synthesised and released into the circulation mainly by macrophages/monocytes and microglial cells upon stimulation by interferon- $\gamma^{9}$. It is said to be excreted mainly through the kidneys in an unchanged form? Glomerular filtration is believed to be the primary mechanism for the renal clearance of neopterin and at least two studies have found a significant inverse correlation between serum neopterin and the creatinine-based estimation of glomerular filtration rate $(\mathrm{GFR})^{14}$. In addition, a number of studies have shown significant positive correlations between the clearance of neopterin and that of creatinine, both in healthy control subjects and in patients with renal disease ${ }^{15,16}$. Serum neopterin has furthermore been shown to correlate with serum creatinine levels in patients with a decline in kidney function ${ }^{14}$. It is therefore obvious that plasma/serum neopterin levels would rise with a progression in renal dysfunction, irrespective of whether cell-mediated immunity increases or not. That could explain the lack of correlations between plasma/ serum neopterin levels and the urine neopterin:creatinine ratio in patients with renal dysfunction and may also explain the results where the urine neopterin:creatinine ratio was superior to plasma as a biomarker ${ }^{16,17,18}$. In line with this, some laboratories express plasma neopterin levels relative to the plasma concentration of creatinine $(\mu \mathrm{mol}$ neopterin in plasma/mol creatinine in plasma) in individuals diagnosed with compromised renal function, thus adjusting for renal dysfunction. This practice could also help to distinguish between raised neopterin levels due to cellular immune activation and that due to renal insufficiency ${ }^{15}$. It is, however, not routinely done and would probably not be an issue in patients with normal renal function. However, as renal function varies in many disorders not primarily associated with renal insufficiency, it may be an oversight. Pertinent to the current discussion is the fact that overestimation of systemic inflammatory activity, when using plasma levels as the biomarker in the face of renal insufficiency, will have a negative impact on the linear relationship between plasma neopterin and the urine neopterin:creatinine ratio.

Another factor potentially confounding the correlation is that neopterin may be synthesised within the renal tissue. Although no such evidence could be found for the healthy kidney, it is feasible to expect intra-renal neopterin synthesis in patients with immune-complex related renal diseases. This has, in fact, been observed in patients with mesangial proliferative glomerulonephritis where indications were found for intra-renal neopterin synthesis and where increased urine neopterin positively correlated with histopathological findings ${ }^{19}$. Under such conditions, increased urine neopterin would reflect macrophage activation and active inflammation within the kidneys ${ }^{19}$. A parallel increase in plasma neopterin would be unlikely. Urine neopterin levels would then be a biomarker for monitoring the progression of the renal disease and not systemic inflammation.

In addition to the impact that a decline in renal clearance and immune-complex related intra-renal activity may have on correlations between plasma/serum neopterin and the urine ratio, renal tubular processes could potentially also have an effect. Early indications suggested that neopterin is not only removed from the circulation by filtration, but that it may also be secreted along the renal tubuli and that neopterin clearance values may be 1.8 times that of creatinine clearance ${ }^{16}$. Although creatinine clearance is clinically used as a measure of GFR, creatinine is, in fact, actively secreted from the peritubular capillaries into the proximal tubule to the extent that creatinine clearance may over- 
estimate actual GFR by $10 \%$ to $20 \% 0^{20}$. With the urine concentration of both substances partially dependent on tubular secretion it should be remembered that tubular secretion is affected by many factors. Tubular secretion of creatinine is, for instance, influenced by physical activity, diet, time of day and several medications ${ }^{20}$. Any factor influencing the secretion of either or both could thus change their ratio in urine and by implication impact on the linear relationship between plasma neopterin and the urine neopterin:creatinine ratio. In addition to the above, circadian rhythms, and therefore time of day when samples are collected, may also influence the relationship. A circadian rhythm in the urine neopterin: creatinine ratio has indeed been shown to exist with peak values at 02:30, mainly due to a dip in creatinine excretion, and again at 06:30, following the peak in the circadian rhythm of plasma neopterin ${ }^{21}$. These variations are said to be less noticeable during day time ${ }^{21}$. This questions the assumption of first or early morning as the best time for specimen collection and stresses the importance for serial assessments to be performed at the same time of day.

\section{Correlations and diagnostic agreement}

As seen from Table 1, significant positive correlations were generally found between plasma neopterin and the urine neopterin:creatinine ratio. However, a statistically significant correlation does not imply diagnostic agreement. This is borne out by results of studies where plasma/serum neopterin levels and the urine neopterin:creatinine ratios were concurrently assessed and both were independently tested as biomarkers. As illustrated in column 5 of Table 1, plasma neopterin and the urine neopterin:creatinine ratio may differ in their diagnostic sensitivity and discriminatory power.

\section{Statistical discussion of correlation versus agree- ment}

From a purely statistical point of view correlations do not equate diagnostic agreement. In order to determine statistical agreement between two quantitative measures, one needs to check whether a $\mathrm{y}=\mathrm{x}$ relationship exists between the measures ${ }^{22}$. Although one would assume that a linear regression or Pearson's correlation analysis $(y=a+b x)$ would be able to determine agreement if the intercept of the regression line (a) equals zero and the slope (b) equals one, this is not the case ${ }^{22}$. The crucial difference between the two types of analyses is that a re- gression or correlation analysis determines the difference between $\mathrm{x}$ and the average of $\mathrm{y}$ (i.e. equality of averages), while agreement determines the equality of individual values $^{22}$. Therefore, one cannot determine quantitative agreement of measures based on equality of means and a high degree of correlation. In order to say that one marker agrees sufficiently and is therefore considered interchangeable with the other, special methods that determine the agreement between individual values, such as limits of disagreement or intra-class correlations, are required ${ }^{22}$.

Although largely beyond the scope of this writing, it is perhaps necessary to mention that increased neopterin concentrations have also been found in cerebrospinal fluid, synovial fluid, pancreatic juice, saliva, ascites fluid, cord blood and broncho-alveolar lavage under localised infectious or inflammatory conditions. Neopterin synthesis is in such cases probably induced in local endothelial cells under the influence of INF- $\gamma^{19,23}$. Neopterin concentration in these fluids may give more direct information on local macrophage stimulation and inflammatory activity. However, collection of such fluids is, in the majority of cases, more invasive.

\section{Conclusion}

Despite the fact that several factors may potentially influence the linear relationship between plasma neopterin and the urine neopterin:creatinine ratio, positive correlations of varying statistical significance generally exist between the two in individuals with normal renal function. This would suggest plasma neopterin and the neopterin:creatinine ratio in urine both to be markers of pro-inflammatory status and suitable for the serial monitoring of disease progression or the effect of therapeutic interventions. However, renal disease can, depending on the type of renal disorder, confound the diagnostic and prognostic value of both plasma neopterin and the urine neopterin:creatinine ratio. Since correlation analysis determines the equality of means and not individual values, statistically significant correlations do not necessarily imply diagnostic agreement.

\section{Conflict of interest}

None

\section{Acknowledgements}

The Staff of the Medical Library, University of Pretoria 


\section{References}

1. Medzhitov R. Origin and physiological roles of inflammation. Nature. 2008;454(7203):428-435.

2. McAfoose J, Baune BT. Evidence for a cytokine model of cognitive function. Neurosci Biobehav Rev. 2009;33(3):355-466.

3. Slavich GM. Understanding inflammation, its regulation, and relevance for health: A top scientific and public priority. Brain Behav Immun. 2015;45:13-14.

4. Straub RH, Schradin C. Chronic inflammatory systemic diseases: An evolutionary trade-off between acutely beneficial but chronically harmful programs. Evol Med Public Health. 2016;2016(1):37-51.

5. Halaris A, Leonard BE. Inflammation in Psychiatry. In: Modern Trends in Pharmacopsychiatry vol. 28. S. Karger AG. 2013. http://www.karger.com/Book/ Home/257496

6. Yirmiya R, Goshen I. Immune modulation of learning, memory, neural plasticity and neurogenesis. Brain Behav Immun. 2011;25(2):181-213.

7. Hunter P. The inflammation theory of disease. The growing realization that chronic inflammation is crucial in many diseases opens new avenues for treatment. EMBO Rep. 2012;13(11):968-970.

8. Bipath P, Levay P, Olorunju S, Viljoen M. A non-specific biomarker of disease activity in HIV/AIDS patients from resource-limited environments. Afr Health Sci. 2015;(2):334-343.

9. Berdowska A, Zwirska-Korczala K. Neopterin measurement in clinical diagnosis. J Clin Pharm Ther. 2001;26(5):319-329.

10. Eisenhut M. Neopterin in Diagnosis and Monitoring of Infectious Diseases. Journal of Biomarkers. 2013. https://www.hindawi.com/journals/jbm/2013/196432/ 11. Fuchs D, Jaeger H, Popescu M, Reibnegger G, Werner ER, Kaboth W, et al. Comparison of serum and urine neopterin concentrations in patients with HIV-1 infection. Clin Chim Acta Int J Clin Chem. 1990;187(2):125-130.

12. Murr C, Widner B, Wirleitner B, Fuchs D. Neopterin as a marker for immune system activation. Curr Drug Metab. 2002;3(2):175-187.

13. Sipahi H, Girgin G, Palabiyik SS, Tutkun E, Yilmaz $\mathrm{OH}$, Baydar T. Possible changes of New-Generation inflammation markers with occupational lead exposure. $J$ Occup Health. 2017 Jul 27;59(4):345-351.

14. Lhee HY, Kim H, Joo KJ, Jung SS, Lee KB. The
Clinical Significance of Serum and Urinary Neopterin Levels in Several Renal Diseases. J Korean Med Sci. 2006;21(4):678-682.

15. Reibnegger G, Fuchs D, Hausen A, Werner ER, Werner-Felmayer $G$, Wachter H. Concentrations of Neopterin in Serum of Recipients of Renal Allografts. Clin Chem. 1989;35(10):2157.

16. Werner ER, Bichler A, Daxenbichler G, Fuchs D, Fuith LC, Hausen A, et al. Determination of neopterin in serum and urine. Clin Chem. 1987;33(1):62-66.

17. Ulker OC, Yucesoy B, Durucu M, Karakaya A. Neopterin as a marker for immune system activation in coal workers' pneumoconiosis. Toxicol Ind Health. 2007;23(3):155-160.

18. Rider LG, Schiffenbauer AS, Zito M, Lim KL, Ahmed A, Zemel LS, et al. Neopterin and quinolinic acid are surrogate measures of disease activity in the juvenile idiopathic inflammatory myopathies. Clin Chem. 2002;48(10):1681-1688.

19. Ueno K, Shimizu M, Yokoyama T, Ishikawa S, Tasaki $\mathrm{Y}$, Inoue $\mathrm{N}$, et al. Urinary neopterin: an immune activation marker in mesangial proliferative glomerulonephritis. Clin Exp Nephrol. 2015;19(2):264-270.

20. Ciarimboli G, Lancaster CS, Schlatter E, Franke RM, Sprowl JA, Pavenstädt H, et al. Proximal Tubular Secretion of Creatinine by Organic Cation Transporter OCT2 in Cancer Patients. Clin Cancer Res. 2012;18(4):1101-1108. 21. Garcia-Gonzalez MJ, Dominguez-Rodriguez A, Abreu-Gonzalez P. Diurnal variations in serum neopterin levels are associated with the pineal hormone melatonin circadian rhythm in healthy human subjects. J Pineal Res. 2006;40(3):288-289.

22. Indrayan A. Clinical Agreement in Quantitative Measurements. In: Doi S, Williams G, editors. Methods of Clinical Epidemiology. 2013.http://www.springer.com/gp/ book/9783642371301

23. Andert SE, Griesmacher A, Zuckermann A, Müller MM. Neopterin release from human endothelial cells is triggered by interferon-gamma. Clin Exp Immunol. 1992;88(3):555-558.

24. Zezulová M, Bartoušková M, Hlídková E, Adam T, Kujovská Krčmová L, Červinková B, et al. Citrulline as a biomarker of gastrointestinal toxicity in patients with rectal carcinoma treated with chemoradiation. Clin Chem Lab Med. 2016;54(2):305-314.

25. Sarac ES, Girgin G, Palabiyik SS, Charehsaz M, Aydin 
A, Sahin G, et al. A pilot study on neopterin levels and tryptophan degradation in zinc-exposed galvanization workers. Biol Trace Elem Res. 2013;151(3):330-334.

26. Kurz K, Teerlink T, Sarcletti M, Weiss G, Zangerle R, Fuchs D: Asymmetric dimethylarginine concentrations decrease in patients with HIV infection under antiretroviral therapy. Antivir Ther. 2012;17(6).1021-1027.

27. Asci A, Baydar T, Cetinkaya R, Dolgun A, Sahin G. Evaluation of neopterin levels in patients undergoing hemodialysis. Hemodial Int Int Symp Home Hemodial. 2010;14(2):240-246.

28. Erturan I, Basak PY, Ozturk O, Ceyhan AM, Akkaya $\mathrm{VB}$. Is there any relationship between serum and urine neopterin and serum interferon-gamma levels in the activity of Behcet's disease? J Eur Acad Dermatol Venereol JEADV. 2009;23(12):1414-1418.

29. Tozkoparan E, Deniz O, Cakir E, Yaman H, Ciftci F, Gumus S, et al. The diagnostic values of serum, pleural fluid and urine neopterin measurements in tuberculous pleurisy. Int J Tuberc Lung Dis Off J Int Union Tuberc Lung Dis. 2005;9(9):1040-1045.

30. Yuksekol I, Ozkan M, Akgul O, Tozkoparan E, AlRashed M, Balkan A, et al. Urinary neopterin measurement as a non-invasive diagnostic method in pulmonary tuberculosis. Int J Tuberc Lung Dis Off J Int Union Tuberc Lung Dis. 2003;7(8):771-776. 